\title{
Of(f) Course: Michel Foucault, the Mobile Philosopher and his Dreamworlds
}

\author{
Author: \\ Dr Marianna Papastephanou, Professor of Philosophy, University of Cyprus, \\ Department of Education, and Professor II, Department of Education, Faculty of \\ Educational Sciences, University of Oslo, Norway edmari@ucy.ac.cy
}

Abstract:

Foucault extolled the Iranian revolution and, anticipating the havoc that his public intervention in favor of the revolution would create, he wrote: 'I can already hear the French laughing, but I know that they are wrong'. Examining Foucault's (so unlikely) valorization of certainty and the partisan affectivity it bestows upon knowledge and truth, I read his unusual engagement with the Iranian revolution against the grain. A major tendency is to approach Foucault's Iranian writings as aberration; against this tendency, I read them as an effect of Foucault's specific epistemic and utopian optics. Through a critical reading of neglected aspects of Foucault's comments on Iran, I argue that much nuance is missing when damning critiques fail to see why and how Foucault's interest in an active rather than folklore non-European political identity unveils deeper tensions of his own worldview and outlook on international politics and interrogates mainstream appraisals of Foucault's political philosophy.

Key words:

Iranian Revolution, parrhesia, utopia, modernization, knowledge, history 


\section{Introduction}

Foucault is 'far too often seen as an essentially Eurocentric thinker who had little to say about the world outside of Europe'. ${ }^{1}$ Yet, Foucault went off-course when, upon accepting a Corriere della Sera journalistic assignment, he traveled to Iran in 1978 and dispatched a series of reportages d'idées. ${ }^{2}$ However, Foucault's fascination with the Iranian revolution exposed his position to unusual public scrutiny and to unprecedented attacks. It has also caused an ongoing controversy concerning how to interpret and critique the intellectual's stand on an issue of international politics. ${ }^{3}$

Readings of Foucault's reportages d'idées may be grouped as critical-explanatory, interpretive-neutral and defensive. ${ }^{4}$ Some of Foucault's detractors have accused him of orientalism, nostalgia and anti-modernism or charge him with Nietzschean and Heideggerian (philosophical and political) complicities. ${ }^{5}$ Such opponents are then accused by some Foucauldians of finger-pointing, moralism and Islamophobia.

There are also middle-ground positions and points of convergence between opponents and proponents. A by now common and pertinent claim in the relevant literature is 'that Foucault's Iranian writings shed light on his work of this period'. ${ }^{6}$ A main tendency is also to concede that Foucault was led astray in the case of Iran and to give one major explanation of this aberration. Most critics imply that, if Foucault had remained within safe territory (instead of exploring uncharted waters), he would not have been blown off-course. For instance, Janet Afary and Kevin Anderson ${ }^{7}$ 'charge that Foucault made fundamental errors of political judgment'; to them, it 'was clearly a misstep in political judgment made in the context of an uncharacteristic foray into topical journalism'. ${ }^{8}$ However, it is striking that, as I explain in a later section, Foucauldian scholars also come to this astonishing, very un-Foucauldian conclusion 
of blaming displacements that set the philosopher off-course. I consider unFoucauldian the underlying assumption that we must limit ourselves to the standard, familiar and safe practice. Contra such explanations and conclusions, I argue that Foucault did not go far enough, beyond his 'internal' epistemic and political borders. His own displacement was too limited to allow him a different optics of Iran due to reasons inter alia embedded in his outlook on epistemology, politics and utopics.

Thus, while acknowledging the significance of the controversy as it has unfolded, I take issue with the tendency toward one explanation. In the effort to defend a clear, argumentative thesis and to stake out a clear debate to engage, most theorists neglect the synergy of important aspects of Foucault's problematic. Ultimately, they reduce political stakes to faulty moral psychology. By contrast, my reading of Foucault's Iranian writings presupposes and operates on a fabric of interwoven immanent and transcendent critiques of Foucault's authorial decisions and positionings. I hope that this reading makes room for a more complex approach to the Iranian writings. This facilitates a multi-faceted epistemic and political account not of what might be said to have 'de-routed' Foucault but of why Foucault was not 'derailed' and 'desubjectivated' enough when discussing Iran. A complex approach to Foucault's Iranian writings may be needed to set on course a more critical outlook on his political philosophy, its reception and hegemony in many fields and its framing of many current understandings of global politics.

\section{The Journey}

Foucault's journey to Iran disrupted the rhythms of an intellectual course inwardly focused on mechanisms of power within Western statehood. Reaching out, moving 
eastward and outside of the archive, Foucault momentarily bracketed his ordinary research patterns to explore utopian possibilities for which he deeply longed. ${ }^{9} \mathrm{He}$ perceived the Iran of 1978 as a radically other, non-European space which could escape modernization. Iran offered him an outward perspective from which to frame a radical alternative to Western modernity.

Indicative of this expectation is Foucault's employment of the Iranian uprising as a topical illustration of why and how a revolt is politically, ethically and aesthetically superior to the modern revolutionary spirit. In making this point, Foucault also criticized the centripetal and domesticating way in which public opinion gets interested in what happens elsewhere:

After I left Iran, the question that I was constantly asked was, of course: "Is this revolution?" (This is the price at which, in France, an entire sector of public opinion becomes interested in that which is "not about us"). I did not answer, but I wanted to say that it is not a revolution, not in the literal sense of the term, not a way of standing up and straightening things out. ${ }^{10}$

What is, then, for Foucault, a revolt which escapes the confines of Western modernity and deserves the fascination that he felt?

It is the insurrection of men with bare hands who want to lift the fearful weight, the weight of the entire world order that bears down on each of us, but more specifically on them, these oil workers and peasants at the frontiers of empires. It is perhaps the first great insurrection against global systems, the form of revolt that is the most modern and the most insane'. ${ }^{11}$

To the surprise of many Foucauldian disciples, Foucault is thrilled rather than appalled by the religiousness of the revolt, which he sees as an instantiation of political spirituality. ${ }^{12}$ His enthusiasm ${ }^{13}$ is for a spirituality that produces resistant subjectivities and for a political fervor long forgotten in the West. 
Foucault's likely and unlikely reading of the revolt does not apply his usual, complex categories of power other than sporadically (e.g. the panoptical gaze of the shah ${ }^{14}$ ). It resorts to more conventional conceptual tools, involving a vocabulary of victims, domination and liberation. Foucault stresses the paradox of barehanded defeat of a most powerful army and praises unity over Babel-like multivocality. For him, typical of this revolt is that it 'has brought out - and few peoples in history have had this - an absolutely collective will'. Until his journey, collective will was to Foucault 'a political myth with which jurists and philosophers try to analyze or to justify institutions' and 'a theoretical tool: nobody has ever seen the "collective will" and, personally, I thought that the collective will was like God, like the soul, something one would never encounter'. ${ }^{15}$ His journey to Iran familiarizes Foucault with the possibility of an effected consensus - not of the Habermasian, communicativerationality type (which Foucault disliked), but one secured by a religious spirit which annuls internal disputes and is not based on the force of the better argument. For Foucault, this rare concordance erupts in the quotidian and changes its course: 'I don't know whether you agree with me, but we met, in Tehran and throughout Iran, the collective will of a people. Well, you have to salute it; it doesn't happen every day' ${ }^{16}$

The collectivity which Foucault encounters is no culturalist folklore but an operative and energetic national (id)entity ${ }^{17}$ which produces a political will against institutionalized power. In yet another unlikely move, Foucault challenges social construction with a segment of reality, for he contrasts real national consciousness to the fabricated one of Shah's 'liberal' nation-building: 'because it was the Shi'ite religion that in fact constituted the real principle of national consciousness, Reza Shah, in order to dissociate the two, tried to propagate a notion of "Aryanness", whose sole support was the myth of Aryan purity'. Against liberal instrumentalist 
assumptions that people can identify with just any constructed identity/imaginary community, Foucault emphasizes grassroots resistance: 'in the eyes of the people, what did it mean to discover one fine day that they were Aryans? It was nothing more than seeing the two-thousand year-old monarchy being celebrated today on the ruins of Persepolis' 18

Foucault may have wrongly valorized that specific theorization of patriotism and that specific version of nationalism in Iran. ${ }^{19}$ But I find it important that, even in this way, Foucault's position complicates current facile treatments of collective affect and acknowledges the affective as a real and potentially enabling force of resistance. What Foucault embraced in Iran subverts many positions that have been held in his name within academic discourses. Strikingly, Foucault's certainties affirm a patriotic idiom of insurrection where an unusual 'rejection of foreigners' is not a sign of xenophobia but a national affirmation of self-determination and resistance against global meddlers:

Of course, in the independence struggles, in the anticolonial wars, one finds similar phenomena. In Iran the national sentiment has been extremely vigorous: the rejection of submission to foreigners, disgust at the looting of national resources, the rejection of a dependent foreign policy, the American interference that was visible everywhere, have been determinants in the shah's being perceived as a Western agent. But national feeling has, in my opinion, been only one of the elements of a still more radical rejection: the rejection by a people, not only of foreigners, but of everything that had constituted, for years, for centuries, its political destiny. ${ }^{20}$

Unlike current approaches which overlook effects of international hegemonies and reify global pathologies through a handful of key-words of evil where xenophobia prominently figures, Foucault's position involves a nuanced fear of foreigners. The philosopher who inspired generations of disciples to give xenophobia the status of the utmost political problem and explanatorily to reduce to xenophobic-nationalist reaction just any critical-patriotic resistance to intervention justifies 'rejecting 
foreigners' as a sign of rejecting dependence. 'What' were the foreigners that Foucault loathed? Not the category of foreigner as such, as his critics (eager to find contradictions and failures) assume, but the geopolitical category of meddlers. Taking the 1953 Iran coup as an example, we may personify this category through liberals such as 'ambassadors and military advisers actively participating in the overthrow' of Mossadeq; CIA and MI6 agents who 'distributed "grey propaganda", funded demonstrations, played "dirty tricks"'; those who 'urged officers to carry out the coup' against Mossadeq; Americans and British who ‘worked through local Nazis, and had a direct role in kidnappings, assassinations, torture, and mass street killings' ${ }^{21}$

However, Foucault is not only hostile to geopolitical foreign meddling but also to modern intellectual infectious rationalism translated into bourgeois politics. Ironically, the mobile philosopher who, at more sedentary moments, politicized the modern fear of contamination by otherness (the 'erring' other, the perverse, the mad, etc) now considers modern influences threatening (in the political sphere rather than in that of individual encounters). Though Mossadeq's resistance could have offered Foucault a more democratic example of alternative to the shah, Foucault is suspicious of modern elements in Mossadeq's legacy. Hence, Foucault taxonomically orders secular and democratic Iranian opposition as 'bourgeois-nationalist' ${ }^{22}$ or 'socialistoriented'. ${ }^{23}$ Foucault has been accused of orientalism, but, I think, precisely the point about contamination justifies one commentator's view that his is an 'inverted Orientalism'; ${ }^{24}$ for, Foucault's dreamworld is of authentic and pure Otherness uncontaminated by Western modernity. ${ }^{25}$ Foucault claims that Iranian people categorically rejected modernization, for he declares just any modernization dead in its tracks. Thus, Foucault as a 'Western traveller appears to have stumbled upon a 
univocal mass whose spiritual elation' will compensate 'for the grueling labor and material burdens of the premodern life to which they are more than willing to return in order to fend off the deadening, corrupting influences of Western industrialism's "world without spirit", 26

The dystopian regime of the shah invited Foucault's critical-utopian response. The utopian vision in question was of a processual, formalist kind where the content of the utopia (in this case, the specific version of Islamic politics and how it positions diverse citizens) did not matter. Foucault's Iranian, indeterminate utopia evokes rupture, exceptionalism, exalted alternatives to modernism typical of much French postmodern thought mixed with a curiously and strikingly modernist glorification of natality. This natality, the 'birth of ideas' at which the philosopher wants to be present is evident in the following extract from his November 1978 text:

There are more ideas on earth than intellectuals imagine. And these ideas are more active, stronger, more resistant, more passionate than "politicians" think. We have to be there at the birth of ideas, the bursting outward of their force: not in books expressing them, but in events manifesting this force, in struggles carried on around ideas, for or against them' ${ }^{27}$

Likewise, Foucault utopianizes the non-abstract character of the revolt: 'this collective will, which, in our theories, is always general, has found for itself, in Iran, an absolutely clear, particular aim, and has thus erupted into history'. ${ }^{28}$

Foucault rejoices in the political possibilities that he attaches to eruptive and disruptive energy. But he will see those possibilities shattered less than a year after making his hopes public. The events in Iran after the success of the revolt made some French intellectuals ${ }^{29}$ in 1979 confident enough to ask Foucault to acknowledge his error of judgment. Foucault responded by reminding them of his work on confession 
and of his bios theoretikos, i.e. his avoidance of public polemics. Foucault would not respond to the content of the charges "because throughout "my life" I have never taken part in polemics. I have no intention of beginning now'. Foucault's averted gaze had 'another reason, also based on principles. I am "summoned to acknowledge my errors." This expression and the practice it designates remind me of something and of many things, against which I have fought' ${ }^{30}$

Slightly later, he responded to the accumulated evidence of the revolt having gone awry with the rhetorical modality of Kantian-like principle/maxim: 'One must be respectful when a singularity arises and intransigent as soon as the state violates universals'. ${ }^{31}$ Significantly, this is found in Foucault's last self-standing commentary on Iran entitled: 'Is It Useless to Revolt?’ This title evokes an important, Kantreminiscent retrieval of use-lessness against glorifications of utilitarian logistics of gains and losses. In the same commentary, Foucault prepares the ground for the above, principled conclusion about singularity and universality with the following aphorism: 'It is certainly not shameful to change one's opinions, but there is no reason to say that one's opinion has changed when one is against hands being chopped off today, after having been against the tortures of the SAVAK yesterday'. ${ }^{32}$

After May 1979, Foucault is thought to be back on course. Commentators overlook Foucault's later interview (May 22, 1981) with Jean François and John de Vit ${ }^{33}$ where Foucault was asked: 'You said in an interview in 1973, I think, that you were opposed to popular tribunals. You made reference to the example of China. One could also speak today of Iran, where the Ayatollah Khomeini no longer even knows how many people must be executed. What do you think of these tribunals?' (263). ${ }^{34}$ Foucault responded as follows: 
You know perfectly well that if we created juries that were entirely popular, the death penalty would be applied to everyone, even the most minor thieves. So there is this background of social warfare: he who steals wages war; he who is robbed fights the one who stole. This should not be forgotten. So it is necessary to have the courage to say that justice serves to prevent this rather than to translate it. The popular tribunal translates it. Khomeini is precisely this. Once again, this discussion was misunderstood. People saw an apology for this form of justice that is not even a kind of popular tribunal, but rather the cutting of throats. No, no. ${ }^{35}$

\section{Aberration}

Later responses to Foucault's Iran episode range from scathing attacks to condescending reactions. As such, the journey and the related writings are mostly treated as aberration. From the Latin 'aberro', 'wander away, go astray', in the same etymological family with error, ${ }^{36}$ aberration comes to normalize reverent readings of Foucault that set Iran aside or to support moralist readings that dismiss Foucault wholesale. The philosopher-wanderer's momentary departure from what was typical of him or expected from him is thus considered a deviation from his usual course. To opponents, the normal route from which Foucault was derailed explains the aberration as the inevitable result of a politically complicit Lebensphilosophie à la Nietzsche and Heidegger. To proponents, the aberration is ignored/forgotten/forgiven; or useful in a merely scholarly, detached way. The latter position considers Foucault misguided concerning Iran but focuses more on how his Iranian writings can nevertheless illuminate his work or how his work illuminates those writings exegetically rather than critically.

I argue that Foucault's Iranian experience and writings should neither be theorized through idioms of inadvertence and misdirection nor presented as a matter of prognostication and clear vision of the future. As I see it, the whole issue does not boil down to unpredictability of the revolutionary outcome, which was not, in any case, of 
much interest to Foucault. Indeed, Foucault was no seer and he should not be expected to be one. But, I argue later, there is, to a degree, an issue of blindness and deafness to facts happening there and then and to warnings made by a woman interlocutor who parrhesiastically confronted Foucault in a newspaper letter. Blindness and deafness, evident in his Iranian writings, support the argument that Foucault was epistemically and politically not adequately displaced when approaching Iran. Why? In my view, because those Foucauldian certainties that devalued episteme, judgment, and fact- or evidence-based history made him utopianize a specific politicization of religion and led him to project his own hopes onto the revolt. The philosophical dreamworld of Foucault (his imaginary philosophical universe) did not contain evidence-based knowledge: 'I dream of the intellectual destroyer of evidence' and of the intellectual who 'incessantly displaces himself $\cdot{ }^{37}$ Such certainties along with his missing bits of knowledge about Iran allowed him a limit-experience ${ }^{38}$ that had only belated self-displacing effects. ${ }^{39}$

\section{Knowledge(s)}

In 'À quoi rêvent les Iraniens?' [What are the Iranians dreaming about?], Foucault extolled Iranian 'political spirituality' and, anticipating reactions, he wrote:

The other question concerns this little corner of the earth whose land, both above and below the surface, has strategic importance at a global level. For the people who inhabit this land, what is the point of searching, even at the cost of their own lives, for this thing whose possibility we have forgotten since the Renaissance and the great crisis of Christianity, a political spirituality. I can already hear the French laughing, but I know that they are wrong. ${ }^{40}$

Foucault's (so unlikely) assertion of the confident, knowing subject and the erring other, and the partisan affectivity it bestows upon knowledge and truth, invite the 
question: did Foucault know in the 'savoir' or in the 'connaissance' sense? With 'savoir,' Foucault denotes a process through which one changes 'in the course of the work that one does in order to know'. By contrast, connaissance enables multiplication of 'the knowable objects', manifestation of 'their intelligibility' and understanding of 'their rationality, while maintaining the fixity of the inquiring subject'. ${ }^{41}$

What work did Foucault do in order to know about Iran and to be so certain that critics were wrong? The performativities of Foucault's passage ${ }^{42}$ above subvert the rigidity of the distinction between savoir and connaissance since, evidently, savoir and self-displacement can produce certain (qua confident) inquiring subjects too. And is the criterion of transformation of the self enough for dichotomizing connaissance and savoir? In some cases (political issues notwithstanding), only a much needed multiplication of objective knowledge may generate more radical and desirable selfdisplacement. A process of setting subjective change on course, on its own and irrespective of validity claims and propositional truth-content, does not suffice for something to qualify as normatively significant transformative knowledge.

Self-displaced or not (or partly), Foucault emerges throughout 'À quoi rêvent les Iraniens?' as a master of a truth opposed to the French 'regime of truth' for the sake of a people whose dreams were a question and in question. In this sense, Foucault undergoes a transmutation from specific to universal intellectual, at least to the extent that, as a philosopher, he speaks the truth 'to those who had yet to see it, in the name of those who were forbidden to speak the truth' ${ }^{43}$

Specific or universal, the mobile philosopher, upon return, as a parrhesiast, challenges public opinion with the piece of truth that he encountered. 'The parrhesiastes (one 
who speaks the truth) does not doubt' that 'he or she disposes of the truth, as this does not refer to an irrefutable proof or "certain" knowledge. What is at stake is the courage to speak the truth in relation to oneself and the others ${ }^{44}$ - we may ask: independently of propositional content, of solid knowledge, of proof of a kind? The mobile intellectual's 'I know that they are wrong', was followed by: 'I who know very little about Iran'.45

\section{Parrhesia}

For Foucault, in the 'inability to establish that full, adequate, and sufficient relationship to ourselves, the Other intervenes'; she 'meets the lack' and 'makes up for this inadequacy through a discourse' 'that is not the discourse of truth through which we can establish, fasten, and close up on itself the sovereignty we exercise over ourselves'. ${ }^{46}$ How did the Other intervene in the philosopher's parrhesia on the issue of Iran? Let me add another parrhesiast, not a 'laughing French', but a migrant Iranian woman, 'Atoussa H.', who wrote a newspaper letter, the first challenge to Foucault on Iran. In the relevant source, she is described as a 'leftist Iranian woman living in exile in Paris'; ${ }^{47}$ writing 'a brief November 1978 letter to the editors of Le Nouvel Observateur criticizing Foucault'; and 'an Iranian feminist' who signed with the pseudonym 'Atoussa H. . ${ }^{48}$ The placing of Atoussa into the designation 'feminist' is, to my knowledge, Afary and Anderson's, and not Atoussa's self-description. This operation of Afary and Anderson (and of related sources) is interesting in itself. When it comes to self-description and identity, Atoussa identifies herself in her letter only as an 'Iranian' (i.e., again, interestingly, through ethnic-national/state identity) 'living in Paris' ${ }^{49}$ 
Atoussa designates those who support an Islamic government as 'French Leftists': 'Living in Paris, I am profoundly upset by the untroubled attitude of French leftists toward the possibility of an "Islamic government" that might replace the bloody tyranny of the shah'. She personalizes this designation with Foucault: 'Michel Foucault, for example, seems moved by the "Muslim spirituality" that would advantageously replace, according to him, the ferocious capitalist dictatorship that is tottering today'. 50

Atoussa responds to Foucault's praise on political spirituality with a plea to seek a piece of knowledge/evidence: "in order to have an idea of what the "spirituality" of the Quran, applied to the letter under Ayatollah Khomeini's type of moral order, would mean, it is not a bad idea to reread the texts'. ${ }^{51}$ The subtext which legitimizes her savoir work for constructing knowledge evokes research strategies of textual support, close reading and, I dare say, 'local' and 'particular' knowledges of the kind that Foucault had valued in his contrast to universally ambitious knowledge. On this point (and later), her letter is marked by ellipsis inserted by the newspaper editor ${ }^{52}$ who shortened her letter possibly for manageability reasons of paid space, space paying off, space saved for other purposes. The 'liberal' Iranian censorship of the shah's regime finds here a transmutation into another, certainly incomparably 'milder', 'liberal' managerial veiling: we will never know Atoussa's full argument, whether the omitted chunks made sharper criticisms or were irrelevant or repetitive. This 'veil of ignorance' will let us have only the following citation for judging what Atoussa saw in Islamic sources - de-contextualizing the extracts, of course, and itself being somewhat de-contextualized due to the imposed ellipsis that precedes and follows it, but a challenge to Foucault nevertheless. 
[ ... ] Sura 2: "Your wives are for you a field; come then to your field as you wish". Clearly, the man is the lord, the wife the slave; she can be used at his whim; she can say nothing. She must wear the veil, born from the Prophet's jealousy toward Aisha! We are not dealing here with a spiritual parable, but rather with a choice concerning the type of society we want. Today, unveiled women are often insulted, and young Muslim men do not themselves hide the fact that, in the regime that they wish for, women should behave or else be punished. ${ }^{53}$

Her textual operations then shift from religious hermeneutics to political contrast:

Foucault's idealized picture of his dreamed, imminent heterotopia is set against the dystopian, concrete and accomplished Saudi Arabian Islamic heterotopia.

'Spirituality? A return to deeply rooted wellsprings? Saudi Arabia drinks from the wellspring of Islam. Hands and heads fall, for thieves and lovers' ${ }^{54}$

Atoussa's contrast may be criticized for relying on an operation of homology that levels Saudi Arabian, Suni politics with the as-yet unaccomplished political 'experiment' of Shi'ite Iran. The two cases (and corresponding countries) were very different also in socio-political conditions in ways that invite cautious nuance rather than homogenization or interpretations of Iran through the lens of Saudi Arabia. But, in his response, Foucault did not opt for such a refutation of Atoussa's contrast, which requires more detail or more Habermasian dialogical-argumentative engagement. We may extrapolate from his other Iranian writings that he might have had the difference in Suni and Shi'ite religiousness in mind when he sweepingly accused Atoussa of dismissing Islam in one blow. Nevertheless, beyond Atoussa's contrast, the discussion of Saudi Arabia alongside Iran would be very revealing of the double-standards of the West and the material motivations behind them. Most critics who see their countries' politics of siding with the shah as deriving from a genuine concern with human rights and liberalization forget to answer the question: why has the liberal US wholeheartedly supported Saudi Arabia all along? 
Be that as it may, Atoussa perceptively unveils what I see as an often unwittingly enacted subtle racism on the part of many Western scholars: to expect or summon that the Other accept a regulation, a measure, a settlement that those scholars would never accept for themselves and for their own countries. 'It seems that for the Western Left, which lacks humanism, Islam is desirable . . for other people'. ${ }^{55}$ By contrast, we may add in hindsight, the rights of the Western self (the deconstructionist and critical intellectual included) are non-negotiable, regardless of varied deconstructions, reformulations or multi-perspectival critiques of human rights discourses.

Atoussa then challenges Foucault by speaking with the voice of a cautious 'we', qualified by the quantifier 'many': 'Many Iranians are, like me, distressed and desperate about the thought of an "Islamic" government' ${ }^{56}$ Why? Atoussa explains her position through recourse to local (insiders') knowledge: 'We know what it is. Everywhere outside Iran, Islam serves as a cover for feudal or pseudorevolutionary oppression' ${ }^{57}$ Here we have a leap on her part from the actual to the possible. Does the actual rule out the possibility of a new and different start, a re-interpretation or even transcendence of the religious passages in question and the related practices? Would that not be an Islamophobic sweeping incrimination of any fresh Islamic effort? Indeed, Foucault charges her with Islamophobia, yet without unpacking the point. We may extrapolate from the rest of Foucault's Iranian writings that the answer he might have given comes from how he viewed Shi'ite priesthood and reinterpretation of religious texts.

Among the Shi'ite clergy, religious authority is not determined by a hierarchy. One follows only the one to whom one wants to listen. The Grand Ayatollahs of the moment, those who, in facing down the king, his police, and the army, have just caused an entire people to come out into the streets, were not enthroned by anybody. They were listened to. This is true even in the smallest communities, where neighborhood and village mullahs gather around themselves those attracted by their words. From these volunteers comes their subsistence, from them comes 
what is necessary to support the disciples they train, and from them comes their influence. ${ }^{58}$

Foucault attaches to this kerygmatic anarchy an unusual and unlikely vocabulary of praise on 'denouncing injustice', singling out culpabilities and prescribing: 'But from them also comes the unrelenting plea to denounce injustice, to criticize the government, to rise up against unacceptable measures, and to mete out blame and to prescribe' ${ }^{59}$ Foucault, the social philosopher, blithely focuses on actual agents (in this case, the Ayatollahs) dealing out justice. He rejects only philosophically authorized normativity, because he sees it as shaping moralist subjects by dictating or prescribing how they should be, but this rejection does not extent to the authority of the local agent.

To return to Atoussa, it is very clear that she also condemns the West-supported tyranny of the shah and acknowledges that 'Islam-alas! -is the only means of expression for a muzzled people'. But she pleas for more knowledge: 'the Western liberal Left needs to know that Islamic law can become a dead weight on societies hungering for change. The Left should not let itself be seduced by a cure that is perhaps worse than the disease' ${ }^{60}$

Was the mere intervention of the parrhesiast Other enough to disrupt the matter of course of the philosopher's utopian set destination? Does this dialogical exchange between subjects speaking their truth (regardless of judgment of content) enact and deliver the political goods that some Foucauldians expect from parrhesia?

Foucault responds to Atoussa's parrhesia with opaque engagement, selective attention and a mixture of averted and downward ${ }^{61}$ gaze. His 16 lines begin with the complaint that Atoussa 'did not read the article she criticizes'. We may ask: is it enough just to 
speak 'your truth' in the name of polysemy and non-fixity of meaning and selfhood? Certainly it is not enough for Foucault who focuses on some of the content of the letter and on its performativity and who indicates that a good reading and a correct interpretation (against misreading) are important steps prior to speaking publicly. But, somehow, it seems enough for many Foucauldians who are enthusiastic about parrhesia and celebrate the claim of speaking the truth rather than the claim to truth and to its testing.

Foucault, indeed, accuses Atoussa of misreading him. Now propositional content, accuracy and validity claims acquire significance. Before speaking one's truth one must read and get the content of what is read right. 'If there had been in Mme. H.'s letter only a misreading, I would not have responded to it'. Just as Foucault overlooks the parrhesiast's (i.e. Atoussa's) concerns about women and does not comment on them, he might as well ignore a letter that, in misreading him, ceases to merit a response.

But it [Atoussa's letter] contains two intolerable things: (1) It merges together all the aspects, all the forms, and all the potentialities of Islam within a single expression of contempt, for the sake of rejecting them in their entirety under the thousand-year-old reproach of "fanaticism". (2) It suspects all Westerners of being interested in Islam only due to scorn for Muslims. What could we say about a Westerner who would scorn Islam? The problem of Islam as a political force is an essential one for our time and the coming years. In order to approach it with $a$ minimum of intelligence, the first condition is not to begin by bringing in hatred. ${ }^{62}$

Though the prescience and pertinence of the last sentence cannot be overestimated, it should not obscure other operations of the above passage. Mobilized to answer by the 'intolerable' and lumping all reaction into the category of hatred, Foucault psychologizes and de-materializes Atoussa's ethico-political objections. Any disruption of the liberal fantasy of conflict- and politics-free possibility within heterotopian otherness is de-politicized and reduced to phobias and hatred between 
internal divisions of Otherness (e.g. secular, migrant Iranians and religious, rooted Iranians).

Ironically, another point that Foucault ignored in his response was Atoussa's following accusation and objection about Foucault's position on minorities: 'It is also written that minorities have the right to freedom, on the condition that they do not injure the majority. At what point do the minorities begin to "injure the majority"?', 63 Atoussa's objections unveil the unexpectedly liberal substratum of Foucault's position on negative duties of avoiding injury. However, Foucault's reliance on a 'negative freedom' outlook concerning the relation of minorities and majorities is not as unjustifiable as Atoussa implies. In fact, her objection reflects an overgeneralization easily deconstructible through many historic-political examples of minorities ruling over majorities or being strategically manipulated ${ }^{64}$ for effecting undemocratic impositions upon majorities. Consider, for instance, the ruling few of ancient empires, later of the ancient regime and of class divisions. The numerical meaning of minority is different from the value added to it when used to signify the suppressed, weak and exploited. There is no compelling argument why the term 'minority' should always designate the morally appealing category of the victim or of the oppressed. This positioning of the numerically few should be examined through evidence and work that one has to do in order to know the share enjoyed by a minority in a specific distribution of the real (if I may use J. Rancière's parlance here). Atoussa romanticizes minorities (and Foucault quite often did the same in his other writings, as is typically done today too). A minority, politically weak in some ways due to numbers, may in other ways be, again, politically, very strong and regulatory due to powerful positioning within the partage du sensible. Nevertheless, as concerns Iran's 
specific conditions since 1979 and indications of this course already in 1978, Atoussa's objection was to the point.

Foucault perhaps felt that Atoussa had been interpellated to speak as a Western, modernized, rational subject. More generally, he must have felt that the Western lack of sympathy toward Iran reflected Islamophobia, ignorance of Western criminal meddling, a modern-liberal self-satisfaction with secularism and a developmentalism that saw the shah as the authoritarian yet tragic figure who had to keep up the modernization vision while ruling backward people. ${ }^{65}$ Against assuming traditionalreactionary inadaptability to liberalization Foucault emphasized that Iranians are denouncing 'a modernization that is itself an archaism' ${ }^{66}$

\section{Dreamworld}

Foucault defensively connects the obligation to pay attention to utopian Islamic possibility with the ultimate legitimacy that heroic thanatos bestows upon a movement (a recurrent theme in Foucault's Iranian writings). 'Since people protested and were killed in Iran while shouting "Islamic government", one had an elementary obligation to ask oneself what content was given to the expression and what forces drove it' ${ }^{67}$ Thanatoptic, thanatourist, the long-established interest of the traveler in actual forces of change blocks attention, let alone response, to Atoussa's interrogation of the utopianization of the current, to her plea for subjectivities that have to be created beyond available, drastic choice. For Atoussa had asked: 'after twenty five years of silence and oppression, do the Iranian people have no other choice than that between the SAVAK and religious fanaticism?'. ${ }^{68}$ 
Foucault probably noticed only the desperate tone of the question, rather than its content, and normalized it as just another sign of Western publics' perceptible annoyance against which he had already set his own mobilization: 'What is it about what has happened in Iran that a whole lot of people, on the left and on the right, find somewhat irritating? The Iran affair and the way in which it has taken place have not aroused the same kind of untroubled sympathy as Portugal, for example, or Nicaragua'. ${ }^{69}$ Foucault castigates the averted gaze when foreign politics is concerned and the western habitual reaction of indifference to news that would spoil one's holidays. 'I'm not saying that Nicaragua, in the middle of summer, at a time when people are tanning themselves in the sun, aroused a great deal of interest' ${ }^{70}$ But, in the case of Iran, he detects an unusual reception of a rebellion against a most horrific regime whose liberal gloss had being constructed by its Western allies. 'I soon felt a small, epidermic reaction [on the part of the Western public] that was not one of immediate sympathy'.71

However, Atoussa's question about a way beyond the drastic choice of the shah and Khomeini and her temporal qualification of it with the phrase 'after twenty five years of silence and oppression' operates within what I term 'boundary discourse', exploding perceived limits and creating spaces of distance from binarisms such as Islamophilia/Islamophobia and 'modernization'/spirituality. Foucault cannot answer her question not only because he focuses on actual social agents but also because, following his usual course, he seeks in Iran the non-liberal/non-modern, eruptive, radical Other. Atoussa demarcates the middle and transcending ground not just as future possibility but also as a counterfactual, past opportunity nipped in the bud: her metonymic poles of undesirable choice, SAVAK and Khomeini, are temporally 
juxtaposed to 25 years of silence and oppression. What alternative path was blocked exactly 25 years before that summer of 1978 ?

I can think of many summer events in various elsewheres that did not manage to disturb the merry tanning, but one of those events is most relevant here. ${ }^{72}$ In August 1953, a UK and US orchestrated coup deposed Iran's democratic leader Mossadeq, restored the shah to power and 'modernized' the organization of the SAVAK. The global publics (especially of the involved countries) missed the event during the timehonored snoring in the sun-bed. That summer (and until 1978) Foucault had not gone off-course; he had written nothing about Iran.

In August 1953, Foucault holidayed in Italy, where he re-read Nietzsche's Untimely Meditations through a Heideggerian lens. ${ }^{73}$ Still, Atoussa's subtext of the Mossadeq alternative could strike a note of familiarity, though in a 25 years hindsight effect: Foucault, who knew little about Iran, must have heard much about the coup at a time when the remembrance of what was violently stopped from becoming an actual force was both dim and painful. In the Iranian imaginary, the coup was a tragic lesson in inability to defeat the 'liberal' West by the liberal means of Mossadeq. What had led Foucault astray, the faith in the nouveau and inconnu, rupture and radical force, had, for different reasons, led astray many secular Iranians who had embraced Khomeini. Western 'liberalism' could not be deposed by irenic tactics such as Mossadeq's. It could only be overthrown, and was in fact deposed, by non-liberal forces. Foucault concurred with some secular Iranians on the idea that Khomeini was produced by a desperate political resort to the only existing force that could at that time depose the shah. $^{74}$ 
Foucault, nevertheless, comes across as knowing too little about the 1953 coup.

'Oddly enough, in his extensive reporting on the revolution's genesis, Foucault makes only sporadic, quite uninformative reference to the Mossadegh matter'; ${ }^{75}$ oddly also for the philosopher who acknowledged foreign interference, he overlooks 'the latest in a series of foreign interventions and imperialist indignities to which Iran had been subjected since the dawn of the century' (ibid). ${ }^{76}$ His lack of knowledge matched his concern 'to see that blame for the traumas Iran's "modernization" had produced stayed affixed to the Pahlavis, two dictatorial rulers whom he stereotypically configures as classic Oriental despots'. Hence, 'the often covert, though nonetheless weighty forces of Empire-Czarist Russian, British, and their American postwar incarnation-are, in effect, relegated to the margins of his analysis and thus de facto diminished in their significance' (ibid). The traveling philosopher, coming from a Fernand Braudel context of historical research, was a newcomer to geopolitical situations which, to be understood, also require event-based historiography.

Foucault was unable to answer Atoussa's plea for another solution away from the drastic choice also because, against 'the "bourgeois nationalism" of Mossadeq', ${ }^{77}$ he had endorsed Khomeini's religious nationalism. Given Foucault's standard positions (from which Iran did not manage to displace him), Mossadeq was not just a historically bypassed force; he was too 'Enlightened', 'modern' and committed to counterfactual humanist possibilities such as democracy, women's rights, human rights and progress to merit Foucault's interest. Some of present-day Foucault's detractors ignore (as much as he did) that the concatenated effects of the coup blocked alternative paths. Or, worse (and unlike Foucault) they gloss over the horror of the shah regime and the complicities of Anglo-American governments. Against such sanitizations, Reza Baraheni, the Iranian scholar and poet who was imprisoned by the 
shah, detailed in 1976 the connection between the coup against Mossadeq, the

Western role in it and the regime that was thus established since $1963 .{ }^{78}$ Ervand

Abrahamian also helps us take notice of the now ignored facts:

the coup tarred America with the British brush: being perceived as the "colonial power", a perception that created deep distrust between Iran and United States. It set up a dictatorship that became increasingly unpopular and corrupt. It put a nail in the coffin of the same monarchy by inseparably linking it to the imperial powers. It discredited the army by identifying it with the shah, the CIA, and the MI6. It destroyed the secular parties - both the Tudeh and the National Front - and so paved the way for the emergence of Khomeini's religious opposition. The "neutralist" Mossadeq was exchanged for the "fundamentalist" Khomeini. The Mossadeq movement failed to bring national liberation; but the same liberation eventually came in the shape of the Khomeini movement. The coup's imprint on Iranian culture was equally deep: the suspicion that sinister "foreign hands" controlled Iran; and the conviction that only force could forestall repetition of 1953. In short, the coup struck a hard blow at liberalism as well as at socialism and secular nationalism. ${ }^{79}$

But, sharing with his later detractors a similar neglect of some historical details, Foucault swung into an (un)timely self-interruption in 1978 that, ironically for the archaeologist and genealogist, did not go back enough. Although we may agree with Scullion $^{80}$ that 'Foucault's actual motivations cannot now be determined with any certainty', we may add that Foucault's certainties about complicities of knowledge and Enlightened reason, his formalist utopics and his then anti-modern passion blocked a view of past counterfactual possibilities. Foucault's lack of adequate displacement also blocked attention to then-contemporary warnings (such as Atoussa's) that could have produced a synergy of foreboding and more radical and nuanced critical position.

In Foucault's eyes, Iranians (unlike Marxist and utopian socialists) were dreaming about nothing other than the removal of the shah. 'Furthermore (and here one can speak of Khomeini's political sense), this collective will has been given one object, one target and one only, namely, the departure of the shah' ${ }^{81}$ Devoid of the content 
that would specify or indicate the direction in which the torrential current was drawing Iran, Foucault's dreamworld of political spirituality, hazy in the distance, was praised for absence of long-term plans (an absence enabling volonté general) and for formalist-processual negativity. In my view, perhaps there is no better example than Foucault's fascination with the (real or imagined) ethico-political void and seriality attributed to Iranian mobilization for illustrating what is wrong with formalist utopias and with the facile assumption that minimalism and indeterminacy protect from degenerations into totalitarianism. ${ }^{82}$

As for what he philosophically dreamed about, as I have already indicated, in Foucault's philosophical dreamworlds of dichotomous, enthusiastic prose, judgment is indicted and contrasted to exalted alternatives such as imaginary leaps, creativity and elation: 'I can't help but dream about a kind of critique that would try not to judge but to bring an oeuvre, a book, a sentence, an idea to life'. The critique that he idealized (in other words, the critique of his dreams) 'would light fires, watch the grass grow, listen to the wind, and catch the sea foam in the breeze and scatter it'. Such a critique 'would multiply not judgments but signs of existence; it would summon them, drag them from their sleep. Perhaps it would invent them sometimes — all the better'. The other kind of critique, that which 'hands down sentences', 'sends me to sleep; I'd like a critique of scintillating leaps of the imagination'. ${ }^{83}$

\section{Conclusion}


While a traveler in Iran, Foucault perceived a utopian impulse of quasi-libidinal investment in the urgent demand to get rid of the shah and an unwavering commitment to such a formalist vision even at the cost of death (the fighter's own, but, after the victory, chiefly of others). Thanatoptic, thanatourist, the 'innocent', curious gaze of the Western traveler reveals a philosophical dreamworld of elation and fascination with 'real life' rather than with weighing evidence, judging and obtaining knowledge. While apparently off-course (moving eastward and away from state-centred methods), Foucault gazed at Iran through the lens of his certainties and fixations.

At least, his was an engaged eye. But this does not make up for a blindness and deafness that has not been just Foucault's. In this sense, against the tendency to view the Iran episode in Foucault's intellectual life as aberration, I have argued that it unveils deeper tensions of his outlook on knowledge, utopia and international politics. It interrogates mainstream dependencies on Foucault's political philosophy and endorsements of his mistrust of knowledge. Finally, it presents a challenge to current, culturalist understandings of world politics that operate through categories of anonymous power and neglect geopolitical, global agents and complexities of eventbased history and international relations.

\section{Bibliography}

Abrahamian, E. “The 1953 Coup in Iran”. Science \& Society 65, no 2 (2001): 182215.

Afary, J., and Anderson, K. B. Foucault and the Iranian Revolution: Gender and the Seductions of Islamism. Chicago: University of Chicago Press, 2010. 
Ahluwalia, P. "Post-structuralism's Colonial Roots: Michel Foucault". Social Identities 16, no 5 (2010): 597-606.

Alshaibi, W. "The Intellectual Destroyer: Michel Foucault and the Iranian Revolution". Undergraduate Honors Theses. Paper 758. University of Colorado, 2015. http://scholar.colorado.edu/cgi/viewcontent.cgi?article=1953\&context=honr theses Accessed 17 August 2018.

Atoussa, H. "An Iranian Woman Writes". In: Foucault and the Iranian revolution: Gender and the seductions of Islamism. Eds. Afary, J., and Anderson, K. B., 209-210. Chicago: University of Chicago Press, 2010.

Baraheni, R. "Terror in Iran". http://www.rezabaraheni.com/wpcontent/uploads/2014/10/Terror-and-Iran-New-York-Review-of-Books-10-28-76.pdf, 1976.

Beaulieu, A. "Towards a Liberal Utopia: The Connection between Foucault's Reporting on the Iranian Revolution and the Ethical Turn". Philosophy \& Social Criticism 36, no 7 (2010): 801-818.

Eden, S. A. The Memoirs of the Rt. Hon Sir Anthony Eden: Full Circle. London: Cassell, 1960.

Elahi, B. "East-Struck: Janet Afary and Kevin Anderson's Foucault and the Iranian Revolution in Context". Human Studies 30, no 2 (2007): 157-166.

Eribon, D. Michel Foucault: Eine Biographie. Hans-Horst Henschen (trans). BadenBaden: Suhrkamp, 1993.

Foucault, M. Michel Foucault Live: Collected Interviews, 1961-1984. Ed. S. Lotringer. Trans. Hochroth and J. Johnston. Boston: Semiotext(e), 1996.

Foucault, M. “The Masked Philosopher”. In Essential Works of Foucault, Volume I: Ethics, Subjectivity, and Truth. Ed. Paul Rabinow. Trans. Robert Hurley et. al. New York: New Press, 1997.

Foucault, M. Essential Works of Foucault 1954-1984: vol 3, Power. Ed. J. D. Faubion. Trans. Robert Hurley et.al. New York: New Press, 2000.

Foucault, M. The Hermeneutics of the Subject: Lectures at the Collège de France, 1981-1982. Ed. Frédéric Gros. Trans. Graham Burchell. New York: Macmillan, 2005.

Foucault, M. "Foucault and His Critics". In Foucault and the Iranian revolution: Gender and the Seductions of Islamism. Eds. Janet Afary and Kevin Anderson, 181267. Chicago: University of Chicago Press, 2010. 
Foucault, M. Wrong-doing, Truth-telling: the Function of Avowal in Justice. Eds. Fabienne Brion and Bernard E. Harcourt. Trans. Stephen W. Sawyer. Chicago: The University of Chicago Press, 2014.

Honig, B. "What Foucault Saw at the Revolution: On the Use and Abuse of Theology for Politics". Political Theory, 36, no 2 (2008): 301-312.

Jabri, V. "Michel Foucault's Analytics of War: the Social, the International, and the Racial”. International Political Sociology 1, no 1 (2007): 67-81.

McCall, C. “Ambivalent Modernities: Foucault's Iranian Writings Reconsidered”. Foucault Studies 1, no 15 (2013): 27-51.

Papastephanou, M. Educated Fear and Educated Hope: Dystopia, Utopia and the Plasticity of Humanity. Rotterdam: Sense Publishers, 2009.

Papastephanou, M. "Michel Foucault's limit-experience limited”. Educational Philosophy and Theory 50, no 4 (2018): 390-403.

Scullion, R. "Michel Foucault the Orientalist: On Revolutionary Iran and the "Spirit of Islam"”. South Central Review 12, no 2 (1995): 16-40.

Smeyers, P. and Waghid, Y. "Cosmopolitanism in Relation to the Self and the Other: From Michel Foucault to Stanley Cavell". Educational Theory 60, no 4 (2010): 449467.

\footnotetext{
${ }^{1}$ Ahluwalia, "Post-structuralism's colonial roots", 598.

${ }^{2}$ For more information on the number of Foucault's journalistic pieces, his related interviews and responses, and on the details of his journeys to Iran, see Afary and Anderson, Foucault and the Iranian Revolution.

${ }^{3}$ Jabri, "Michel Foucault's analytics", 67.

${ }^{4}$ Alshaibi, "The Intellectual Destroyer", 2.

${ }^{5}$ For an informative account, see Elahi, "East-Struck", 158.

${ }^{6}$ McCall, "Ambivalent Modernities", 30.

${ }^{7}$ Janet Afary and Kevin Anderson are the scholars who edited all of Foucault's writings on the Iranian revolution in English and drew the Anglophone world's attention to his Iran experience. For their sharp criticisms of Foucault, see their comments on Foucault's essays on Iran in Afary and Anderson, Foucault and the Iranian Revolution.

${ }^{8}$ Honig, "What Foucault Saw", 2.

${ }^{9}$ Despite the well-known, Foucauldian dismissive comments on utopias, his writings on Iran are fraught with utopian elements. For a discussion of such elements, see Beaulieu, "Towards a liberal Utopia”.

${ }^{10}$ Foucault, "Foucault and His Critics", 222.

11 Ibid.

${ }^{12}$ Beaulieu, "Towards a liberal Utopia".

${ }^{13}$ Significantly, enthusiasm originates from en + theos, 'breathing god into the other' or 'feeling god', and such connotations are especially relevant to the political elation of the revolt and of Foucault's reception of it.

${ }^{14}$ Foucault, "Foucault and His Critics", 197-8.

${ }^{15}$ Foucault, "Foucault and His Critics", 253.

${ }^{16}$ Ibid.

${ }^{17}$ I approach some individual and collective identities not only as real and existent (in a non-essentialist sense) but also as invested with libidinal energy. I would argue that they are, inter alia, Id-entities. But
} 
this is merely stated here for reasons of clarity. It cannot be argued out for reasons of space and of remote relevance to the main argument.

${ }^{18}$ Foucault, "Foucault and His Critics", 196.

${ }^{19}$ Arguing this point out would sidetrack us here, but the claim will become clearer in a later section where I contrast Mossadeq's nationalism with the 1978 Iranian religious nationalism.

${ }^{20}$ Foucault, "Foucault and His Critics", 253.

${ }^{21}$ Abrahamian, "The 1953 coup", 184. Operations of such meddlers, rightly condemned by Foucault, and certainly not limited to Iran, also involved the following: 'British officials assured others, as well as themselves, that the National Front [Mossadeq's party - M.P.] was "nothing but a noisy bunch of malcontents"; that Mossadeq - a "wily Oriental" - was "wild", "erratic", "eccentric", "crazy", "gangster-like", "fanatical”, "absurd", "dictatorial”, "demagogic", "inflammatory", and "singlemindedly obstinate"; and that Iranians were by nature "child-like", "tiresome and headstrong", "unwilling to accept facts", "volatile and unstable", "sentimentally mystical", "unprepared to listen to reason and common sense", and "swayed by emotions devoid of positive content". Abrahamian, "The 1953 coup", 193.

${ }^{22}$ Foucault, "Foucault and His Critics", 221.

${ }^{23}$ Ibid, 203.

${ }^{24}$ Alshaibi, "The Intellectual Destroyer", 13.

25 This orientalism is inverted because, unlike the standard attitude toward what is seen as authentic in the East (and further on) amenable to a Western lens of modernizing intervention, it turns the East into a positive category that should resist Western intervention and remain pure and uncontaminated by Western categories.

${ }^{26}$ Scullion, "Michel Foucault the Orientalist", 24.

${ }^{27}$ Quoted in Afary and Anderson, Foucault and the Iranian Revolution, 3.

${ }^{28}$ Foucault, "Foucault and His Critics", 253.

${ }^{29}$ I am referring to Claudie and Jacques Broyelle's article in Le Matin, March 24, 1979. See Afary and Anderson, Foucault and the Iranian Revolution.

${ }^{30}$ Foucault, "Foucault and His Critics", 249.

${ }^{31}$ Foucault, "Foucault and His Critics", 267.

32 Ibid, 266.

${ }^{33}$ Foucault, Wrong-doing, truth-telling, 253-269.

${ }^{34}$ Ibid, 263.

${ }^{35}$ Ibid, 264.

${ }^{36}$ Error's etymology and meaning: "a deviation from truth made through ignorance or inadvertence, a mistake," also "offense against morality or justice; transgression, wrong-doing, sin;" from Old French error "mistake, flaw, defect, heresy," from Latin errorem (nominative error) "a wandering, straying, a going astray; meandering; doubt, uncertainty;" also "a figurative going astray, mistake," from errare "to wander; to err". From early 14c. as "state of believing or practicing what is false or heretical; false opinion or belief, heresy." From late 14c. as "deviation from what is normal; abnormality, aberration." From 1726 as "difference between observed value and true value."

http://www.etymonline.com/index.php?term=error

${ }^{37}$ Foucault, Michel Foucault Live, 225.

${ }^{38}$ For a discussion of the Iran episode in association with Foucault's limit-experience, Papastephanou, "LimitExperience Limited".

${ }^{39}$ Some commentators (e.g. Beaulieu, "Towards a liberal Utopia”) explain Foucault's later work as a displacement to an important degree influenced by his Iran experience of disillusionment.

${ }^{40}$ Foucault, "Foucault and His Critics", 209 (my italics).

${ }^{41}$ Foucault, Essential Works of Foucault, 256.

${ }^{42}$ In a like manner, performativities of some of his other works which reveal the subject as a meticulous reader of archives sensitive to appropriate judgment deconstruct or complicate his rhetorical, declarative and constative-level assertions about the 'intellectual destroyer of evidence'. ${ }^{43}$ Foucault mentioned this in his interview with Gilles Deleuze in 1972. For the full transcript, see https://libcom.org/library/intellectuals-power-a-conversation-between-michel-foucault-and-gillesdeleuze Accessed, 20 December 2017.

${ }^{44}$ Smeyers and Waghid, "Cosmopolitanism, self and other", 457.

${ }^{45}$ Foucault, "Foucault and His Critics", 298.

${ }^{46}$ Foucault, The Hermeneutics of the Subject, 378.

${ }^{47}$ Afary and Anderson, Foucault and the Iranian Revolution, 91.

${ }^{48}$ Ibid, 181. 
${ }^{49}$ I see her as a masked parrhesiast whose pseudonym, Atoussa, is to me yet another puzzle. What's in this name and why does she choose it? Being the name of the ancient emperor Darius' wife, is this pseudonym a subtle reference to a pre-Islamic Persian past where a woman was an empress? What about imperialism, conquest and the oppression of large populations? What are we to make out of this pseudonym for the identity of the author? Does the author unveil herself as a feminist unaware of other political undertones of what she subscribes to?

${ }^{50}$ Atoussa, “An Iranian Woman Writes", 209.

${ }^{51}$ Ibid.

${ }^{52}$ Afary and Anderson, Foucault and the Iranian Revolution, 93.

${ }^{53}$ Atoussa, “An Iranian Woman Writes", 209.

${ }^{54}$ Ibid. Consider here how Foucault, who, in his response to Atoussa, bypassed this objection, later comes to acknowledge the newly accomplished reality of violence by using terms similar to those of Atoussa about heads and hands falling. In his last response to the Iran issue that I have cited in a previous section, he mentioned: 'People saw an apology for this form of justice that is not even a kind of popular tribunal, but rather the cutting of throats. No, no' (Foucault, Wrong-doing, truth-telling, 264). Consider in a like manner Foucault's statement that 'It is certainly not shameful to change one's opinions, but there is no reason to say that one's opinion has changed when one is against hands being chopped off today, after having been against the tortures of the SAVAK yesterday' (Foucault,

"Foucault and His Critics", 266).

${ }_{55}^{55}$ Atoussa, "An Iranian Woman Writes", 209.

${ }^{56}$ Ibid.

${ }^{57}$ Ibid.

${ }^{58}$ Foucault, "Foucault and His Critics", 202.

${ }^{59}$ Ibid.

${ }^{60}$ Atoussa, "An Iranian Woman Writes", 210 (my italics).

${ }^{61}$ Consider here, for instance, Foucault's concluding sentence that 'In order to approach [Islam] with a minimum of intelligence, the first condition is not to begin by bringing in hatred'. Foucault, "Foucault and His Critics", 210 (my italics).

${ }^{62}$ Foucault, "Foucault and His Critics", 210 (my italics).

${ }^{63}$ Atoussa, "An Iranian Woman Writes", 209.

${ }^{64}$ Consider here Hitler's manipulation of the Sudeten minority.

${ }^{65}$ Foucault, "Foucault and His Critics", 195.

${ }^{66}$ Ibid.

${ }^{67}$ Foucault, "Foucault and His Critics", 210.

${ }^{68}$ Atoussa, "An Iranian Woman Writes", 209 (my italics).

${ }^{69}$ Foucault, "Foucault and His Critics", 250.

${ }^{70}$ Ibid (my italics).

${ }^{71}$ Ibid, 195.

${ }^{72}$ I refer here to places in whose 'destiny' roughly the same Western 'meddlers' (chastised by

Foucault) were deeply implicated. I place the category of the meddler in quote-marks because I believe that it itself requires a deconstruction of its possibly de-materializing undertones. Meddling evokes a negative sense of curiosity, inquisitiveness, blundering interest on others' affairs, and other such connotations that obscure material, profit- or geopolitics-related reasons for interfering or regulating extra-state, even global issues.

${ }^{73}$ Eribon, Michel Foucault: Eine Biographie, 92.

${ }^{74}$ Consider here also Foucault's opening sentences in 'À quoi rêvent les Iraniens?' about the Western hold on Iran: "“They will never let go of us of their own will. No more than they did in Vietnam." I wanted to respond that they are even less ready to let go of you than Vietnam because of oil, because of the Middle East'. Foucault, "Foucault and His Critics", 203. Foucault was correct on that, and something similar concerned another 'elsewhere': Cyprus in 1955. Anthony Eden's cynical admission in his memoirs that Cyprus could not be given self-determination due to oil verifies Foucault's geostrategic analysis more broadly. For Eden (Eden, The Memoirs of Eden, 415), the British had a strong claim in Cyprus so long as British 'industrial life depends on oil supplies from the Persian Gulf'. ${ }^{75}$ Scullion, "Michel Foucault the Orientalist", 26.

${ }^{76}$ Ibid.

${ }^{77}$ Foucault, "Foucault and His Critics", 221.

${ }^{78}$ Baraheni, "Terror and Iran". Baraheni inter alia wrote: 'The CIA re-created the monarchy, built up the SAVAK and trained all its prominent members, and stood by the Shah and his secret police as their powerful ally. Iran became the police state it is now'. Material from his text (and weighing evidence would be a valuable operation here) is very useful for challenging the position of some Foucauldian 
commentators (both opponents and proponents) who seem to assume that, the 'liberal' support to shah's 'liberalizing' politics by 'liberal' states was, despite some failures, liberal or at least more liberal than what followed. Consider, for instance" "thousands of men and women have been summarily executed during the last twenty-three years. More than 300,000 people have been in and out of prison during the last nineteen years of the existence of SAVAK; an average of 1,500 people are arrested every month. In one instance alone, American-trained counterinsurgency troops of the Iranian Army and SAVAK killed more than 6,000 people on June 5, 1963. According to Amnesty International's Annual Report for 1974-1975 "the total number of political prisoners has been reported at times throughout the year [1975] to be anything from 25,000 to 100,000"'. 'Martin Ennals, secretary general of Amnesty International, reports in his introduction to Baraheni's book: "The Shah of Iran retains his benevolent image despite the highest rate of death penalties in the world, no valid system of civilian courts and a history of torture which is beyond belief." And consider the following as concerns what some Western liberal states had supported and intellectuals had overlooked; what realities give to collective identity a gruesome though politically operative twist (i.e. people unite in suffering, torture and, ultimately, in the determination to free themselves from oppression); and Baraheni's faith in some modern principles while unmasking the betrayal of (and lip service to) those principles (and of modernization) by the 'liberal' shah and his 'liberal' allies: 'There were days when seven prisoners of diverse backgrounds were pushed into this cell. We got ourselves accustomed to sleeping while standing. Some had dysentery because of bad food and fear. Some could not stand because of sore feet or burned backs or pulled out toenails. We breathed into each other's faces. All of us had been kidnapped by the SAVAK; none of us had seen any warrants. Nobody outside knew where we were. We didn't know ourselves where we were, because we had all been brought to the prison blindfolded. The seven of us could have easily run a school, or a supermarket, or a factory. Imagine 100,000 educated men and women in prison while 75 percent of the whole nation is illiterate! Imagine hundreds of doctors in prison when every fifty villages in the country have only one doctor! Imagine roads awaiting construction while engineers are rotting in jails!'. And: 'Of the fourteen people I met in prison cells during my imprisonment in 1973, at least two had been asked to become members of the SAVAK, and upon refusal they had been tortured. Everything I had said during my stay in the US in the academic year of 1972-1973, before my imprisonment, had been reported to SAVAK, which operates on a global scale', ibid.

${ }^{79}$ Abrahamian, "The 1953 coup", 213-4.

${ }^{80}$ Scullion, "Michel Foucault the Orientalist", 36.

${ }^{81}$ Foucault, "Foucault and His Critics", 252.

${ }^{82}$ On my objections to formalist and indeterminate utopias and for my defense of a degree of utopian determinacy, see Papastephanou, Educated Fear.

${ }^{83}$ Foucault, "The Masked Philosopher", 323. 